Bożena STAWOSKA-JUNDZIŁŁ

(Bydgoszcz, UKW)

\title{
MALE DZIECI W CHRZEŚCIJAŃSKIEJ EPIGRAFICE MIASTA RZYMU I W NAUCZANIU JANA CHRYZOSTOMA
}

Ukończyłam niedawno badanie inskrypcji łacińskich, będących fundacjami chrześcijan z Rzymu, a odnoszących się do dzieci w wieku do siedmiu lat. Badana populacja objęła prawie dwa tysiące dzieci z Rzymu i około czterysta z terenów pozarzymskich (zbiór E. Diehla napisów łacińskich) jako materiał porównawczy ${ }^{1}$. Tablice zawierające te inskrypcje wykonano między III a VI wiekiem, głównie od IV do połowy VI wieku. Poza badaniami archeologicznymi, zwłaszcza pochówków dziecięcych, epitafia są jedynym bezpośrednim źródłem, które umożliwia zbliżenie się do świata odczuć i zachowań zwykłych wiernych, czy w ogóle ludności późnorzymskiej i początków rządów barbarzyńskich ${ }^{2}$. Nie ma bowiem innych przekazów o życiu małych dzieci w Rzymie oraz stosunku do nich rodziców i opiekunów, a przecież była to największa gmina chrześcijańska w państwie rzymskim i później pod panowaniem barbarzyńców. Odnośnie Rzymu mamy pojedyncze wzmianki u Grzegorza Wielkiego, a słynne listy „wychowawcze” Hieronima nie dotyczą, poza drobnymi aluzjami, dzieci najmniejszych, przed osiągnięciem wieku szkolnego. Nie ma także bliższych relacji, na czym polegała opieka Kościoła nad sierotami. Mówią o tym natomiast, choć w specyficzny sposób inskrypcje. Warto przyjrzeć się, co na temat małych dzieci uczył zmarły 1600 lat temu złotousty kaznodzieja i patriarcha Konstantynopola Jan Chryzostom († 407).

Epitafia dla dzieci, tak jak i dla dorosłych, nie są treściowo zbyt rozwinięte, ani - na szczęście dla historyków - nie cechują się zbyt sztywnym formularzem, co oznacza brak możliwości ustalenia indywidualnych relacji opieku-

\footnotetext{
${ }^{1}$ Por. B. Stawoska-Jundziłl, Vixit cum parentibus. Dzieci $w$ wieku do siedmiu lat $w$ rodzinach chrześcijan z Rzymu III-VI wieku, Bydgoszcz 2008; Inscriptiones christianae urbis Romae septimo saeculo antiquiores. Nova Series, vol. 1-10, ed. A. Silvagni - A. Ferrua - D. Mazzoleni - C. Carletti, In Civitate Vaticana 1922-1992 (= ICUR), jako uzupełnienie wykorzystałam także kilkadziesiąt epitafiów dla dzieci, które nie ukończyły 8 lat; Inscriptiones Latinae Christianae Veteres, vol. 1-3, ed. E. Diehl, Berolini 1925, 1927, 1931 (= E. Diehl).

2 Terminów „barbarzyńcy”, „poganie” używam jako prostszych niż „niechrześcijanie” lub „Nierzymianie”, bez konotacji pejoratywnych.
} 
nów z dziećmi. Te, które badałam mają jedną cechę wspólną - podawanie wieku zmarłych dzieci, dzięki czemu mogłam z fundacji rodzicielskich wyróżnić te dla małych dzieci. Najprostsze zawierają tylko imię (wtedy pojedyncze) i wiek dziecka. W nieco bogatszych, obok tego występują także drobne elementy ikonograficzne, listki, kropki lub chryzmony. W dłuższych epitafiach pojawiają się również epitety dotyczące zmarłych dzieci, określenia tego, co je spotkało i czeka po śmierci, a także terminy związane z samym faktem śmierci i pochówku. Tu też podaje się także dane konkretne: o czasie śmierci, dacie pogrzebu (o wiele częściej), rzadko o dacie chrztu. W takich napisach są również wzmianki o fundatorach, najczęściej rodzicach, rzadziej samym ojcu lub matce, najrzadziej dziadkach, rodzeństwie lub opiekunach. Zamiast informacji o fundatorach często pojawia się tylko dedykacja dla córki lub syna.

Najmniej informacji dotyczy życia dziecka, z czego wnioskujemy, że nie potrafiono wyartykułować opisów codziennych zachowań niemowląt i dzieci kilkuletnich lub uznawano je za niegodne uwiecznienia. Pozostają nieliczne wyrazy zachwytu nad wyjątkowością dziecka, jego pięknem, zdolnościami przejawianymi w rozpoczętej dopiero nauce (to zwłaszcza w stosunku do najstarszych w tej grupie 6-7 latków). Nie ma także na ogół wyraźnie i wprost zdefiniowanych uczuć fundatorów tablic odnośnie faktu śmierci dzieci, jak i tego, co czuli wcześniej do żyjących poza najczęściej stosowanymi epitetami dulcissimus, -a, carissimus, - a.

Rozkład ilościowy omawianych danych, to kilkanaście epitafiów dla noworodków do miesiąca życia, nieco ponad dwieście dla dzieci do roku, a około 700 dla dzieci do ukończonego 3 roku. Skok ilościowy to około 1000 epitafiów wystawionych dzieciom od ukończonych 3 do niepełnych 8 lat. Proporcje między płciami nie są mocno zachwiane, przewaga chłopców zwłaszcza $\mathrm{w}$ grupach 1-3 i 3-7 lat obejmuje tylko nieco ponad 10\%, choć zarówno niechrześcijanie, jak i chrześcijanie na ogół częściej upamiętniali mężczyzn niż kobiety.

Co można wyczytać z analizowanych inskrypcji? W literaturze naukowej panuje zgoda co do wysokiej, a nawet bardzo wysokiej śmiertelności dzieci w Cesarstwie Rzymskim ${ }^{3}$. Tym bardziej dotyczy to okresu panowania najeźdźców w Rzymie i rekonkwisty Bizantyjczyków z racji choćby długotrwałych wojen, co epitafia zdają się potwierdzać nie tylko ilością fundowanych tablic, ale i poprzez świadectwa wysokiej dzietności, która trwa czasami wyjątkowo długo, do ponad 30 lat u kobiet, a małe dzieci mają mężczyźni po 50 roku życia. Oznacza to $\mathrm{w}$ wielu przypadkach powtórne, a nawet wielokrotne małżeństwa i fundowanie napisów dzieciom z poprzednich związków, bez zaznaczania tego faktu i różnicowania dzieci. Podobnie zresztą nie widać większych różnic między treściami epitafiów dla chłopców i dziewczynek, różnice wy-

${ }^{3}$ Por. W. Scheidel, Roman Age Structure: Evidence and Models, JRS 91 (2001) 1-26; W. Suder, Census populi. Demografia starożytnego Rzymu, Wrocław 2003 i podana tam literatura naukowa. 
stępują między młodszymi i starszymi - dla tych ostatnich przeznaczano na ogół epitafia nieco obszerniejsze.

Jeśli tablice dotyczyły kilkorga dzieci nie stwierdziłam żadnych preferencji u fundatorów ani co do płci, ani wieku. Jeśli natomiast fundacja dotyczyła zmarłego męża lub żony, i przy tym wspominano o dzieciach osieroconych lub zmarłych, to informacje o dzieciach były o wiele skromniejsze; w stosunku do sierot podawano nawet tylko ich liczbę bez imion.

Dzieci wieloimiennych (najwięcej cztery - kilkanaście przypadków) było o wiele mniej, niż o imionach pojedynczych, choć wiemy, że najczęściej nadawano dwa imiona. Imion ,chrześcijańskich” było więcej, niż się na ogół podaje, bo aż do $20 \%$, a w niektórych grupach kilkanaście procent obejmowały także imiona teoforyczne i mitologiczne ${ }^{4}$. W nadawaniu imion preferowano życzeniowe, które w magiczny sposób mogły przyczynić się do powodzenia w życiu. Nie tylko jednak życzono dominacji, władzy, bogactwa, siły, piękna $\mathrm{i}$ innych cech, oznaczających w potocznym rozumieniu powodzenie $\mathrm{w} \dot{z} y \mathrm{ciu}$. Wiele imion pochodziło od cech wysokiej moralności, surowości, sprawiedliwości, i te, tak jak życzące siły i władzy nadawano także dziewczynkom. Oczywiście, wiele tych imion mogło stracić już dosłowność i nadawano je zgodnie z tradycją rodzinną lub środowiskową, ale zaskakująco mało jest imion pochodzących od ojca, a są imiona nadane przez matkę, najwyraźniej o wyższym statusie niż ojciec.

Fundatorzy, jak pisałam, to głównie grupa anonimowa i rodzice występujący wspólnie. Społecznie większość, z wyjątkiem kilku procent, to humiliores, plebs, wyzwoleńcy i niewolnicy, ale bardzo trudno to ustalić, o ile sami fundatorzy tablic tego nie określilii ${ }^{5}$. W dodatku nie ma różnic treściowych i materialnych między inskrypcjami arystokratów, a stojących społecznie najniżej, ci z warstwy średniej wystawiali czasami sarkofag, a arystokraci prostą tablicę. Fundatorzy, poza nielicznymi wyjątkami, nie chwalą się, jak to było w przypadku tablic niechrześcijańskich, swymi dokonaniami. Jaskrawym przeciwieństwem są za to chrześcijańskie epitafia dla najstarszych zmarłych, mających 70 lat i więcej, gdzie stosunkowo dużo pisano o samych zmarłych i o fundatorach ${ }^{6}$.

${ }^{4}$ Definicja imion „chrześcijańskich” jest różnie ujmowana w literaturze naukowej, i wyznaczenie ścisłych kryteriów nie wydaje się możliwe, a ograniczenie się tylko do imion biblijnych, jak chciał np. Jan Chryzostom, byłoby chyba zbytnim zawężeniem, por. np. E. Wipszycka, Le valeur de l'onomastique pour l'histoire de la christianisation. À propos d'une étude de R.S. Bagnall, ZPE 62 (1986) 173-181; I. Kajanto, Roman Nomenclature during the Late Empire, w: Inscriptiones Sanctae Sedis, vol. 2: Le iscrizioni dei cristiani in Vaticano, a cura di I. di Stefano Manzella, Città del Vaticano 1997, 103-111.

${ }^{5}$ Por. F. Bisconti, Mestieri nelle catacombe romane, Città del Vaticano 2000; D. Mazzoleni, La vita del popolo cristiano a Roma alla luce delle testimonianze epigrafiche (dal III sec. alla fine del VI), w tegoż: Epigrafi del mondo cristiano antico, Roma 2002, 73-84.

${ }^{6}$ Por. B. Stawoska-Jundziłł, Senex Christianus. Ludzie $w$ wieku 70 lat i powyżej $w$ świetle 
Informacje o imionach oraz pokrewieństwie fundatorów i dzieci częściej podawano po imionach dzieci, a także w sporej grupie napisów informowano, że chodzi o rodziców czy ojca, bez podania imion, lub dedykowano epitafium synowi lub córce, bez określenia, o którego rodzica (rodziców) chodzi. Oznacza to wyeksponowanie dziecka i poświęcenie mu całej uwagi.

Wyrażonych wprost opisów relacji wewnątrzrodzinnych prawie nie ma; są tylko nieliczne, wzruszające wzmianki o tym, że dziecko żyło tyle a tyle lat $\mathrm{z}$ rodzicami, lub zmarło w ich ramionach, przeżyło jakiś okres z rodzeństwem. Kilka razy występuje prośba, aby dziecko modliło się w niebie za pozostałych członków rodziny. Nieliczne wizerunki pokazują zabawy dzieci z kółkiem, grzechotką; przeważnie są także niezbyt wysokiej jakości artystycznej portrety dzieci, w większości jednak postarzonych. Opisy bólu i rozpaczy prawie nie wystepują, a wymowa tekstów jest raczej pogodna, czy wręcz radosna.

Zapis długości życia także może świadczyć o dowartościowaniu maluchów. Najczęściej chciano to określić jak najdokładniej, co do dnia, a w kilku procentach nawet co do godzin, czy godziny nocy lub dnia. Te fragmenty epitafiów należą do sfery doczesności, gdyż tylko niektórzy wykraczali poza vixit mówiąc o „porwaniu” do nieba, powrocie do pierwotnego stanu bytowania. Do życia ziemskiego należą także nieliczne dane o czasie narodzin (pojedyncze) i narodzin duchowych, dacie chrztu (natus, $-a$ ). To w połączeniu z datą śmierci lub pochówku pozwala stwierdzić, że chrzczono nie tylko w obliczu śmierci, ale wcześniej, czyli nawet noworodki. Jeśli założyć, że wszystkie pochowane w katakumbach dzieci ochrzczono, to zwyczaj wczesnego chrztu w Rzymie można uznać za rozpowszechniony od IV wieku.

Najwięcej zawołań, aklamacji i formuł dotyczy bytu pośmiertnego. Choć nie są one zbyt zróżnicowane i oscylują wokół pax, qviescit, reqviescit, to nasycenie nimi inskrypcji dowodzi wysokiego napięcia odczuć religijnych. Te odzwierciedla również ikonografia epitafiów, gdzie występują nie tylko chryzmony, jako znaki oddania zmarłego pod opiekę Boga, ale wizerunki zwycięskiej duszy zmarłych dzieci (ptaki z gałązkami, same gałązki palmowe i oliwne) i inne symbole, opowiadające o głębokiej wierze nagrodzonej zbawieniem. Fundatorzy byli pewni, że dzieci są w niebie, a nie w „otchłani”, czekając na sąd ostateczny.

Rodzice $\mathrm{i}$ inni bliscy, fundujący tak małym dzieciom epitafia, dawali znać sobie i członkom gminy wiernych, że dzieci są ważnym składnikiem ich życia, mimo jego kruchości. Poprzez zaznaczanie dat z życiorysu noworodków, niemowląt i małych dzieci najwyraźniej pragnęli zachowywać o nich przekaz w pamięciowych „kronikach” rodzinnych na równi ze starszymi, a właściwie przed nimi, skoro epitafiów dla najstarszych, po 70 roku życia było zaledwie 220, a dla młodych i ludzi w średnim wieku, tylko kilka razy więcej niż

tacińskich inskrypcji chrześcijan z Rzymu (III-VI w.), w: Grecja, Kartagina, Rzym, red. R. Sajkowski - M. Wolny, Olsztyn 2009, 143-171. 
dla małych dzieci. Dzieci były więc jakby ważniejsze niż dojrzali członkowie społeczności, a daty pogrzebów istotniejsze od dat śmierci. Uważam, że w ten sposób zwrócono uwagę na fakty, na które nie miano wpływu, to znaczy wysoką śmiertelność małych dzieci. Uczyniono z tego nie „,dopust Boży”, gdyż oznaczałoby to życie w wiecznej niełasce Boskiej, ale właściwie pozytywny fakt. Bóg, wedle jednej z linii interpretacyjnych, zabierał do siebie szybciej lepszych (stąd pewien wstyd, że niektórzy żyli na tym świecie aż 100 lat), a dzieci dostępując po śmierci obcowania ze świętymi (refrigerium), nawet z Bogiem będą naturalnymi patronami gminy i rodziny. Podawanie daty pogrzebu może przy tym oznaczać podkreślanie ostatecznego rozstania z doczesnością i ziemskimi więzami, stąd też rzadkie stosowanie tradycyjnej formuły domus eterna na określenie grobu, gdyż domem dziecka będzie teraz niebo, choć nigdzie nie określono tak dosłownie przestrzeni nowego bytu dziecka, nawet carmina posługują się pogańskim pojęciem eteru i przestrzeni międzygwiezdnej, jakby chciano się zabezpieczyć przed naruszeniem jakiegoś tabu? Epitafia dziecięce sprawiają wrażenie chęci wyposażenia dziecka w przepustkę do nieba, czegoś w rodzaju egipskiej Księgi Umarłych, przewodnika, tylko to bowiem mogli zrobić rodzice dla tak małej istoty w samotnej podróży w zaświaty.

Duża grupa epitafiów nie ma jednak żadnego z tych elementów, jest tylko imię i wiek. Najprostsze założenie, że chodzi o najbiedniejszych rodziców wolnych i niewolników nie thumaczy podania wieku dzieci. Wczesne epitafia, może jeszcze z końca II wieku zawierały tylko imiona z zawołaniem pax lub pojedynczymi symbolami graficznymi, ale bez wieku, nie chodzi więc także o skromność przed obliczem Boga. Może więc byli to wychowankowie gminy, owe sieroty, o których obok wdów wspomina się jako o częstych obiektach działań dobroczynnych. Podanie wieku „,nagradzało” opiekunów stwierdzeniem, że zajmowano się dzieckiem nie tylko jednorazowo lub przez chwilę8.

Jak taki wizerunek relacji z małymi dziećmi ma się do poglądów Jana Chryzostoma? Zetknięcie się z jego poglądami fundatorów epitafiów mogło być tylko przypadkowe, choć w „społeczności katakumbowej” nie brakuje fundatorów i rodzin o korzeniach wschodnich lub greckojęzycznych. To Chryzostom napisał, jako jedyny w późnym cesarstwie, chrześcijański traktat O wychowaniu dzieci ${ }^{9}$, a jego życie i działalność przypadają na okres nasilone-

${ }^{7}$ Por. G. Sanders, La tombe et l'éternité: catégories distinctes ou domaines contigus? Le dossier épigraphique latin de la Rome chrétienne, w tegoż: Lapides memores, Faenza 1991, 293-331.

${ }^{8}$ Por. J.U. Krause, Witwen und Waisen im frühen Christentum, Stuttgart 1995; A. Di Berardino, La solidarietà: forme ed organizzazione a Roma (secoli $I V-V$ ), w: La comunità cristiana di Roma: la sua vita e la sua cultura dalle origini all'alto medioevo, a cura di L. Pani Ermini - P. Siniscalco, Città del Vaticano 2000, 83-112.

${ }^{9}$ Por. Joannes Chrysostomus, De inani gloria et liberorum educatione, ed. A.M. Malingrey, SCh 188, Paris 1972, tłum. W. Kania, O wychowaniu dzieci, BOK 19, Kraków 2002, 73-105. 
go tworzenia inskrypcji ${ }^{10}$. Nie znaczy to oczywiście, iż zakładam jakieś bliższe relacje między Janem, a twórcami napisów w katakumbach. Interesujące jest natomiast każde zetknięcie poglądów moralistów i teologów z ich potencjalnymi odbiorcami, gdyż obraz zachowań wiernych nie zawsze jest łatwo z ich dzieł odtworzyć.

Stosunek Jana do dzieci jest, jak chyba u większości Ojców Kościoła, ambiwalentny, a zapatrywania na ich zachowanie i specyfikę wieku dość fragmentaryczne, stąd najprościej rozpatrywać je z reprezentowanej przeze mnie perspektywy małego dziecka, przed podjęciem nauki. Nawet Augustyn w swoich Wyznaniach nie poświęcił temu okresowi większej uwagi, choć jego opis wczesnego dzieciństwa jest jednym z istotniejszych wśród dzieł Ojców Kościoła ${ }^{11}$.

Antiocheńczyk przypomina, że dziecko jest radością rodziców i powodem do miłości, a odnosi to w oddzielnych opisach zarówno do ojca jak i matki, uważając jednak, że zbytnie starania o nie odciągają ich od spraw Boskich. W hierarchii rodzinnej, ustawionej pionowo, najpierw według niego jest mążojciec, później żona-matka, a na końcu dzieci, zwłaszcza małe. Chryzostom kieruje swoje nauki przeważnie do mężczyzn, co może oznaczać, że stawiał również i u ojców interesy synów przed dobrem żony ${ }^{12}$.

Dziecko jest niewinne, bliskie Bogu, ale i ono według niego „powinno” cierpieć mimo nie popełnienia świadomie jakichkolwiek grzechów. Poprzez chorobę i śmierć, zdaniem Jana, otrzymają one nagrodę życia wiecznego, tak jak dzieci pomordowane na rozkaz Heroda. W dodatku jako praktycznie bezgrzeszne mogą się za dorosłymi wstawić u Boga. Tak daleko posunięte racjonalizowanie tajemnicy Boskiego postępowania chyba nie do końca trafiało do przekonania rodzicom. Dla Jana, jak i dla wielu starożytnych, „wartość” dziecka wzrastała, gdy mogło się już kształcić, najlepiej w sprawach wiary i moralności chrześcijańskiej ${ }^{13}$.

${ }^{10}$ Por. J.N.D. Kelly, Złote usta. Jan Chryzostom - asceta, kaznodzieja, biskup, thum. K. Krakowczyk, Bydgoszcz 2001, 95-97; ostatnio S. Longosz, Jan Chryzostom, w: Literatura Grecji starożytnej, red. H. Podbielski, t. 2, Lublin 2005, 1044-1056; P. Szczur, Problematyka społeczna w późnoantycznej Antiochii na podstawie nauczania homiletycznego Jana Chryzostoma, Lublin 2008, spec. 293-360.

${ }^{11}$ Por. P. Brown, Augustyn z Hippony, thum. W. Radwański, Warszawa 1993, 20-33.

${ }^{12}$ Por. Joannes Chrysostomus, In epistolam ad Ephesios hom. 20, 8; In Genesin hom. 2, 1; In Matthaeum hom. 72, 5; In epistolam ad Romanos hom. 30, 4; zob. M. Falanga, Il pensiero pedagogico di Giovani Crisostomo, Bari 1981; A. Bober, Rodzina kościołem domowym wedlug św. Jana Chryzostoma, VoxP 5 (1985) z. 8-9, 193-200; H. Wójtowicz, Zadania rodziny chrześcijańskiej w nauczaniu św. Jana Chryzostoma, VoxP 5 (1985) z. 8-9, 201-214; W. Kania, Pierwsza katecheza domowa w ujęciu św. Jana Chryzostoma, VoxP 5 (1985) z. 8-9, 215-222; B. Leyerle, Appeling to Children, JECS 5 (1997) 243-270, spec. 258-266 (Children in Chrysostom's thought); J. Maxvell, Pedagogical Methods in John Chrysostom's Preaching, StPatr 41 (2006) 445-450; Szczur, Problematyka społeczna, s. 327-335 (Wychowanie dzieci) i podana tam literatura.

${ }^{13}$ Por. Joannes Chrysostomus, In Matthaeum hom. 9. 2; 35, 3; 71, 4; 79, 5. 
Nieobce są mu również i inne codzienne sprawy dzieci. Wśród rozsianych po tekstach teologicznych i moralizatorskich przypadkowych wzmianek, mamy nawet obraz rodzących kobiet, dzielnie znoszących bóle porodowe oraz ostrzeżenia, że w czasie ciąży nie można sobie pozwalać na wszystko, gdyż bóle porodowe mogą dopaść w najmniej spodziewanym momencie. Jest także nawiązywanie do ukazywanych w literaturze klasycznej obrazków odstawiania dzieci od piersi (najpewniej po to, aby umożliwić matce ponowne zajście w ciążę) i obrzydzania ich smarowaniem nieprzyjemnymi substancjami; rodzice znoszą wtedy cierpliwie płacz dziecka, aby tylko osiągnąć sukces. Innym razem wzmiankuje, że noworodkom należy podawać miód, co zalecają zarówno lekarze, jak i moraliści okresu klasycznego, a nawet jest wzmianka o przeżuwaniu pokarmu przez niańkę przed podaniem go niemowlęciu ${ }^{14}$.

Problemem największym w okresie poporodowym jest dla Chryzostoma wysoka zachorowalność dzieci, sygnalizowana przez płacz. Mimo sugestii historyków, że może to powodować pewne zobojętnienie rodziców na los noworodków nie ma takiej sugestii u Chryzostoma: nie tylko kobiety, ale i mężczyźni darzą, według niego, uczuciami noworodki i przeżywają choroby małych dzieci, co ułatwia zarówno fakt szybkiego rozpoznawania rodziców, jak i radości przejawianej przez dzieci oraz ich niewinności. Zdaniem złotoustego Kaznodziei, trudności wychowawcze wczesnego okresu życia dziecka wzmacniają później więzi między rodzicami a dziećmi ${ }^{15}$.

Chryzostom poświadcza również, że w jego czasach nadawano dzieciom imiona z myślą o ich magicznym oddziaływaniu, np. przez wróżenie z szybkości palenia się lamp, oraz doradza, żeby nadawać im imiona świętych, czy biskupów, bezwiednie akceptując pogląd, że przez to lepiej zabezpieczą oni swoje dzieci ${ }^{16}$.

Podobnie, jak jego klasyczni poprzednicy, jest czuły na zachowywanie się nianiek, skłonnych niekiedy, według niego, do przekarmiania dzieci. Opisuje także sposoby karmienia i zabiegi matek, by dziecko lepiej jadło. Niewielkie też wzmianki dotyczą toalety niemowląt $i$ ich strojów z przestrogą, aby nie obwieszać kosztownościami małych dzieci, bo przywykną do złego. Mamy także, jak u wielu innych moralistów wzmianki, nie zawsze pochlebne w swej wymowie, o zabawkach dziecięcych, a co rzadkie, obserwację, że małe dzieci bawią się różnymi zabawkami niezależnie od płci, np. chłopcy lalkami, ale u nieco starszych popularne są przede wszystkim zabawy naśladowcze ${ }^{17}$.

${ }^{14}$ Por. Joannes Chrysostomus, In epistolam ad Galatas hom. 4, 2; In Matthaeum hom. 17, 5-6; 18, 5; 30, 6; zob. J. Jundził, Wzorce i modele wychowania w rodzinie rzymskiej okresu III w. p.n.e. - III w. n.e., Bydgoszcz 2001; Leyerle, Appeling to Children, s. 246.

${ }^{15}$ Por. Joannes Chrysostomus, In Matthaeum hom. 9, 1; 15, 26; In Joannem hom. 79, 1; In epistolam ad Titum hom. 5, 5; In epistolam ad Philemonem hom. 2, 2; Quales ducendae sint uxores 3; zob. Leyerle, Appeling to Children, s. 257.

${ }^{16}$ Por. Joannes Chrysostomus, De inani gloria 47-48; De S. Meletio Antiocheno 1.

${ }^{17}$ Por. np. In epistolam ad Romanos hom. 17, 5; zob. Leyerle, Appeling to Children, s. 250-253. 
Jan nie wahał się także ukazywać zaborczej i zazdrosnej miłości obojga rodziców do małych dzieci. Wspominał, że gdy oni widzą, jak dzieci coraz częściej bawią się z rówieśnikami, pod byle pretekstem ściągają je do siebie, a nawet zachęcają niewolników do straszenia ich, aby uciekały i wracały w ramiona rodziców ${ }^{18}$; nie znam tak szczerego, naturalistycznego obrazka w literaturze rzymskiej.

U Chryzostoma zadania wychowawcze pozornie rozkładane są na obojga rodziców, choć we wczesnym okresie życia dziecka widzi on częściej w tej roli matkę i opiekunów: niańki, tutorów, pedagogów i w ogóle niewolników, o których czasami wypowiada się negatywnie, jako dostarczycielach dzieciom złych wzorców zachowań. Ojciec winien wkraczać w momencie edukacji moralnej, opowiadając dzieciom historie biblijne i ucząc je psalmów oraz w ogóle Pisma Świętego, a także w okresie szkolnym sprowadzając dobrych nauczycieli i pedagogów oraz dbając zarówno o to, by ci nie znęcali się nad dziećmi, a dzieci nie dokuczały wychowawcom. Władza ojcowska winna się wyrażać w poczuciu odpowiedzialności za wychowanie dzieci, a nie tylko trosce o ich materialne zabezpieczenie.

Sytuacja małych dzieci pogarsza się zdecydowanie po rozwodzie lub przy powtórnym małżeństwie. Także i on odmalowuje w swym nauczaniu stereotyp macochy wrogiej dziecku z poprzedniego małżeństwa męża. Mimo wszystko jednak dowodzi, że zwłaszcza w sytuacjach konfliktowych, dzieci winny znajdować oparcie u rodziców, razem z nimi jadać główne posiłki, oni zaś zabierać dzieci do kościoła, gorzej - zdaniem naszego Kaznodziei, że także do cieszącego się wówczas złą opinią teatru, jak również opowiadać im różne historie i pouczać w zakresie wiary.

Wychowanie to „lepienie wosku”, ale i dobry przykład. Uznanymi metodami wychowawczymi było naśladowanie wzorca osobowego rodziców i wszystkich stykających się z dzieckiem, zachowanie poprawności w konstruowaniu środowiska rodzinnego (np. brak zbytku) oraz pouczenia. Istotna była także dbałość o bezpieczeństwo dzieci i pouczenie, co takim niebezpieczeństwem może być.

Chryzostom akceptował też surowość i pryncypialność, zwłaszcza ojca, który dla dobra syna m.in. odbiera mu zabawkę na rzecz zajęcia się czymś ważniejszym, po to, by go szybciej nakierowywać na właściwą drogę. Godził się również na kary cielesne (stosowane także przez matkę), ale tak dawkowane, aby dziecko bardziej bało się ich zastosowania, niż ich ponoszenia. Zakłada to niestety wczesną i bolesną dla dziecka tresurę. Nie brak jednak nawiązań do okazywanej przez ojca, bez skrępowania, głębokiej miłości do dzieci, choć w takich miejscach częściej mówi o synu ${ }^{19}$.

${ }^{18}$ Por. Joannes Chrysostomus, In Matthaeum hom. 10, 7.

${ }^{19}$ Por. Joannes Chrysostomus, De inani gloria 20, 22 i 79; In Matthaeum hom. 17, 2; 62, 4; In Genesin hom. 4, 2; 8, 2; In epistolam ad Romanos hom. 18, 1; 29, 4; In epistolam ad Galatas hom. 1, 7; 
Dużym przeżyciem dla rodziny były, jak wspomniałam, choroby dzieci. Jan Chryzostom radził więc, aby nie prowokować losu przysięgami „na głowę dziecka"; wyjątkową brutalnością było także życzenie dzieciom swojego wroga wyszukanych nieszczęśćc ${ }^{20}$. Starano się zatem ratować dzieci zarówno modlitwami, jak i działaniami lekarzy. Jan przestrzegał przed zabobonnymi praktykami, radami „starych kobiet”, stosowaniem substancji i przedmiotów apotropaicznych, jak sól, szkarłatna nitka, oraz przed amuletami i czarami. Zabezpieczać przed tym wszystkim miały także m.in. imiona tworzone od rzek, gdyż największa z nich - Nil, była życiodajna. Na prośby zdesperowanych rodziców sam oferował oparcie w znaku krzyża i małych fragmentów Pisma Świętego traktowanych jako amulety, znane m.in. z wykopalisk w egipskich klasztorach ${ }^{21}$.

Żałoba po stracie małego dziecka była w nauczaniu Jana tak samo głęboka, jak po dorosłym. Moralista pocieszał, że dziecko co prawda nie wróci do domu, ale wkrótce i rodzice połączą się z nim w zaświatach. Innym pocieszeniem jest również to, że dziecko zmartwychwstanie, jest już nieśmiertelne, więc po co okazywać rozpacz, i to przy pomocy pogańskich płaczek, co stanowi grzech: śmierć jest odpoczynkiem w Bogu, a cierpienie w dodatku uszlachetnia i zbliża do Boga. Rozpacz rodziców jest wielka zarówno po stracie jednego, jak i wszystkich, a co najgorsze - po śmierci ostatniego z wielu dzieci. Świadomy tego faktu radzi młodym kobietom, żeby po ślubie były przygotowane na częste porody i cierpienia, a nawet śmierć swoich dzieci. Ideałem dla niego były rodziny wielodzietne, a namawianie do takiego stanu mogło oznaczać, że nie zdarzały się one często. Nie wolno jednak według niego zapominać się w zbytniej trosce o dobra materialne dla licznej rodziny, bo nie tłumaczy to zaniedbań $\mathrm{w}$ drodze ku doskonałości ${ }^{22}$. Z przeanalizowanych przeze mnie inskrypcji wynika, że rodzin wielodzietnych było jednak sporo, jak na tak specyficzny materiał ${ }^{23}$.

Te pozytywne na ogół wzmianki o dzieciach, przetykane są jednak w nauczaniu Jana konwencjonalnymi wtrąceniami o braku zrozumienia przez dzieci najprostszych spraw, o „dziecięcej głupocie” dorosłych, o miałkich zainteresowaniach dzieci i o nikłej wartości ich zabawek, a także o skłonności do gniewu, lenistwie i ich pustocie poszukującej ciągle przyjemności i zabawy,

In epistolam I ad Timotheum hom. 1, 2; In epistolam ad Titum hom. 2, 1; 4, 3; De sacerdotio IV 8; zob. Szczur, Problematyka społeczna, s. 376-410.

${ }^{20}$ Por. Joannes Chrysostomus, De virginitate 49, 4; 61-62; In Matthaeum hom. 19. 8.

${ }^{21}$ Por. Joannes Chrysostomus, In Matthaeum hom. 54, 4; De statuis hom. 19, 4; In epistolam ad Galatas hom. 1, 7; De Macabeis hom. 2.

${ }^{22}$ Por. Joannes Chrysostomus, In Genesin hom. 8, 1; In Matthaeum hom. 31, 3; 31, 5; 69, 3; In epistolam I ad Corinthios hom. 1, 6; 28, 3; In epistolam II ad Corinthios hom. 1, 6; In epistolam ad Romanos hom. 7, 9; 18, 7; In epistolam ad Colossenses hom. 8, 6; In epistolam ad Ephesios hom. 10, 3; In epistolam II ad Timotheum hom. 1, 3; Epistola ad Olympiadem 17; De virginitate 65, 4-5.

${ }^{23}$ Por. Stawoska-Jundziłł, Vixit cum parentibus, s. 467-482. 
które są tylko pozorem życia (np. zabawa w króla), o wręcz trudnej do opanowania „dzikości”, o braku właściwej oceny, co ważne, a co nie, co spotykamy także u wcześniejszych moralistów rzymskich, zwłaszcza u Seneki. Dzieci nie potrafią także opanować gniewu, ,pustego” śmiechu i innych emocji (np. uderzenie $\mathrm{w}$ gniewie kochającego ojca, który za to się nie gniewa, o czym pisze także Seneka) w najmniej odpowiednich momentach, w odpowiedzi na co, za radą Chryzostoma i Seneki, jest ignorowanie tego rodzaju wyskoków, a także łagodne pouczanie i okazywanie miłości. Chryzostom uważa nawet, choć zbyt optymistycznie, że wystarczą tylko dwa miesiące do korekty złego wysławiania się, jednak pod warunkiem, iż oddziaływania w tym kierunku będą prowadzone przez wszystkich domowników. Wydaje się zatem, że mimo wszystko, ewangeliczne wezwanie o dopuszczanie małych dzieci do Chrystusa i ich wielkiej prostocie, wręcz doskonałości, przeważa ${ }^{24}$.

Jak więc porównać zapatrywania i uwagi Chryzostoma z reakcjami rodziców i opiekunów zmarłych dzieci w Rzymie? Niewątpliwie, wspólna jest akceptacja małych dzieci, choć może nieco większa u Rzymian. Świat dziecięcej zabawy jest obecny w inskrypcjach, a w katakumbach przy grobach dziecięcych znajdowano nawet lalki. Różnicę zasadniczą widzę w braku nieco głębszych rozważań o losie dzieci po śmierci oraz - co naturalne - w tendencji do wydoroślania najmniejszych dzieci. Różna jest także baza społeczna inskrypcji, u Rzymian dbały o to przeważnie warstwy niższe, a u Chryzostoma kierowano uwagę raczej na bogatszych. Rodzice z Rzymu starali się niekiedy ukazywać małych zmarłych na wzór dorosłych, a poprzez wzmianki o ich mądrości i o chrzcie czy napomykaniu, że byli katechumenami, przedstawiać ich wizerunki jako dorosłych orantów, zwycięzców wyścigów, a nawet nauczających z katedry (jak mały Chrystus?). Chryzostom natomiast ambiwalentnie, jak i jego chrześcijańscy poprzednicy, opisywał zabawy naśladowcze, zwłaszcza chłopców udających wodzów, żołnierzy i królów. Najważniejsze jednak, że potrafił wczuwać się w reakcje rodziców zagrożonych śmiercią dzieci, starał się ich pocieszać, a to, że wybierał czasami radykalne rozwiązania doradzając, by nie zakładać w ogóle rodziny, było znakiem czasów; sam też niekiedy dostrzegał, zwłaszcza w swym późniejszym życiu, radykalizm swych poglądów, że w wychowywaniu dzieci nie można dążyć tylko do kształtowania ideału żołnierza Chrystusowego lub mnicha.

${ }^{24}$ Por. Joannes Chrysostomus, In epistolam ad Ephesios hom. 20, 9; In epistolam ad Romanos hom. 7, 3; In epistolam ad Galatas hom. 1, 6; In Matthaeum hom. 23, 9; 47, 4; 54, 5; 58, 3; 59, 4; 62, 4; 69, 4; 79, 5; 81, 5; In epistolam I ad Timotheum hom. 6, 1; 9, 2; 11, 3; In epistolam II ad Timotheum hom. 6, 4; Quod nemo laeditur nisi a se ipso 6. 


\section{SMALL CHILDREN IN THE CHRISTIAN EPIGRAPHS OF THE CITY OF ROME AND THE TEACHING OF JOHN CHRYSOSTOM}

\section{(Summary)}

The paper presents the results of studies of epitaphs for children up to almost eight years of age from the city of Rome $\left(3^{\text {rd }}-4^{\text {th }}\right.$ c. - B. Stawoska-Jundziłl, Vixit cum parentibus. Children aged under seven in Christian families from Rome of $3^{r d}-4^{\text {th }}$ c., Bydgoszcz 2008) in comparison with the views of John Chrysostom on the upbringing of small children. The content of over 2000 children from Rome demonstrates a high status of even the youngest offspring in the Christian families from this city. The founders cared for their religious ,endowment”, bestowed their love on them and tried to remember them as members of the family even if they had died after a few days or months. It was unquestionably believed that small children are immediately saved, go to God and commune with the saints. Thanks to this the family could hope for their support and prayers. Whereas, John Chrysostom only casually mentions small children and, what is more, ambivalently: on one hand presenting them on the basis of thorough observations of their behavior and looking after them and on the other hand as mindless creatures, a harbinger of valuable person following the Stoics e.g. Seneca. As far as the most important for me question of the death of small children is concerned he takes a stand similar to that of the Romans. The children are really without sins (they did not commit them consciously) so God shall accept them only through the hardships of illness and death. Now they are asleep (unlike in the studied epitaphs) but they will rise from the dead and join their parents. Thus, the despair after their death is pointless; God decided the best for them. The difference lies in the fact that the founders of epitaphs more decidedly see the perfection of posthumous existence of even the smallest children who there reach their full maturity whereas John does not seem to be interested in this issue since he directs his teaching mostly to maturing and mature Christians in the earthly life and not in the beyond. 
